\title{
Marketing College Sports Teams - A Portfolio Approach
}

Gary Brunswick, Northern Michigan University, USA Brian Zinser, Northern Michigan University, USA

\begin{abstract}
The case involves an athletic director at a fictitious mid-sized university (Northwestern Midwest College) who is thinking about how to enhance the productivity of the investments in the various sports programs on his campus. Using concepts from marketing, this athletic director develops a series of ideas, which could be used to reshape the allocation of resources within the athletic division at his university. Faced with the need to effectively manage enrollments, endowments and the branding of their institutions, colleges and universities are looking to successful sports programs as one way to further differentiate their institution in the marketplace. For smaller and some mediumsized institutions, it is becoming increasingly difficult to field a cadre of successful sports programs which both generate both positive revenues and national exposure for the institution. As a result, some of these schools are beginning to think more critically about the portfolio of sports teams which represent the institution, in an effort to increase the efficacy of those institutional investments.
\end{abstract}

Keywords: Sports Marketing; Higher Education Marketing; Product Portfolio; Product Management

Suggested Courses for the Case: Marketing Management and Strategy; Sports Marketing; Sports Management

\section{INTRODUCTION}

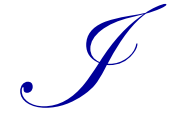

t was a Wednesday afternoon in early May, and Jack "Buzz" Ogaldorf, who is the Athletic Director (AD) at Northwestern Midwest College (a fictitious university, also referred to as NMC), was thinking about all of the various stakeholders and forces influencing the shape and size of the college's athletic programs. Over this past year some teams did well, others not so well in terms of revenue generated, fan attendance, overall record, etc. In a sense, Jack realized he was responsible for a large amount of investments in various athletic programs including men's football, men's ice hockey, men's and women's basketball, soccer, golf, track, alpine and Nordic skiing, and women's lacrosse - the equivalent of running a business worth several million dollars per year. Were those investments wise and appropriate? Should some of those investment dollars be shifted into other athletic programs and endeavors? Jack knew these were important questions to look at, both now and into the future, but how?

In a related way, Jack was reminded of a course he took in his MBA program, focused on marketing strategy, where he learned about the concept of managing a product portfolio. Could this model be used to think about current and future marketing efforts related to NMC's sports programs? Should some programs receive further investment? Others less investment? Should new teams be added, while other teams deleted? What criteria might be used to rationalize these decisions? Jack realized that this would be a good summer research project and started to formulate some ideas in order to "get the ball rolling", to use a sports metaphor.

\section{SPORTS MARKETING AND HIGHER EDUCATION}

The next day Jack begin his summer research project by looking at the impact of marketing on sports programs at colleges and universities, and clearly it was a "big business" and was growing in significance. Increasingly colleges and universities are looking to sports teams and athletic programs in an effort to enhance the image, brand equity and brand awareness of their institution, and are using these efforts to also bolster student recruiting, retention and alumni giving. In fact, the Chronicle of Higher Education (Sander, 2008) reported that Adrian College's enrollment surged $57 \%$ in 3 years after revamping its athletic program in 2005 and admissions became more selective. 
As the sports marketplace becomes increasingly crowded (Leeds, von Allmen, \& Matheson, 2018), both on the professional and on the collegiate level, it is becoming more and more difficult for small and medium sized colleges and universities to be able to support a wide range of sports program which are truly competitive in nature. Additional pressures are being placed upon state-supported / assisted colleges and universities due to funding problems (and a long-term funding decline) in many states; in turn, students, faculty, alumni and legislators are increasingly questioning the allocation of financial resources in areas such as intercollegiate sports. Recently, Virginia pass a state law that limits the amount of subsidy that schools can transfer from other sources to fund athletics (Brady, Berkowitz, \& Schnaars, 2015).

\section{BRAND EQUITY AND COLLEGIATE ATHLETIC PROGRAMS}

As cited earlier, Jack was eager to apply some of the concepts from his MBA class on marketing strategy, where he had learned that the notion of brand equity is a recent one within the marketing discipline. Aaker (1991) has defined brand equity as "the set of brand assets and liabilities linked to a brand, its name and symbol, that add to or subtract from the value provided by a product or service to a firm and/or to that firm's customers". In his later work, Aaker (1996) went on to develop a framework ("The Brand Equity Ten") which further crystallized the measurement and tracking of brand equity:

Loyalty Measures

1. Price Premium

2. Satisfaction / Loyalty

Perceived Quality / Leadership Measures

3. Perceived Quality

4. Leadership / Popularity

\section{Associations / Differentiation Measures}

5. Perceived Value

6. Brand Personality

7. Organizational Associations

\section{Awareness Measures}

8. Brand Awareness

Market Behavior Measures

9. Market Share

10. Market Price and Distribution Coverage

Colleges and universities have also begun to examine the concept of brand equity and use Aaker's "Brand Equity Ten" as it relates to the complete set of operations for the institution, and it would seem that the success (or lack thereof) of the sports programs have a direct impact upon the brand equity for that college or university (Brunswick, 1997). Gladden, Milne and Sutton (1998) have even refined Aaker's framework specifically for brand equity in college sports.

Jack seemed to recall even seeing an article in the Wall Street Journal that placed an estimated \$ dollar value on men's football teams at large universities within the U.S., with some of these teams being worth nearly 1 billion dollars. Coupled with the decline in state-assistance for many colleges and universities and the increasing level of public scrutiny of tax payer expenditures for large sports programs (Brady et al., 2015; Sperber, 2001; Zimbalist, 1999), a strategy to enhance the efficacy of collegiate sports program expenditures is needed, especially for small and mediumsized institutions. One approach might be to employ portfolio theory applied within the confines of NCAA rules and Title 9 requirements (Brunswick, 2005). 


\section{USING A PORTFOLIO APPROACH TO POSITIONING AND BRANDING SPORTS PROGRAMS}

After reviewing material from his MBA marketing strategy course, Jack began to make some notes in an attempt to apply the principles of brand equity and portfolio management. He was quite familiar with sports programs in Wisconsin, given that one of his graduate degrees was earned in that state.

Jack thought that as an example application of portfolio theory (and brand equity) to collegiate sports programs, a 3 tiered approach might be used. Tier 1 would be the largest of the state-supported institutions (i.e., University of Wisconsin - Madison), where a full-complement of NCAA division 1 teams would be deployed, and emphasis (i.e., university support) would be widespread across a range of these sports teams (i.e., men's football, basketball, hockey, women's basketball). The brand equity associated with the school (i.e., University of Wisconsin - Madison) would be somewhat linked to sports team's competing and succeeding in various NCAA post-season tournaments (most sports) and bowl games (football). For Tier 1 institutions in the "Power 5" conferences resources are not a critical issue. Team success is very, very important for many of these schools, and has a clear and direct influence on applications for admission, for example (see Footnote 1).

Tier 2 schools would be medium-sized state-supported schools which have a full-complement of NCAA division 1 teams but have rarely if ever achieved a significant level of success with those programs. A recent report by the NCAA (Fulks, 2015) found that only 20 of the 1,083 college sports programs in the nation are profitable. All athletic departments outside of the Football Bowl Subdivision operate in the red.

Increasingly the expenditures being made on these programs are questioned by students, alumni, state legislators, yet stronger alumni (and alumni groups) also pressure the university administration to maintain the status quo. In some instances, conference realignment has forced schools with marginal athletic programs to seriously consider downsizing or reallocating resources to other sports. Schools in tier 2 are strategically disadvantaged in the sense that there are pressures to support a broad array of sports programs but a lack of resources to propel these programs to high levels of success. The University of Alabama at Birmingham (UAB) is an example of this; UAB announced its plans to shutter their Division I men's football program in December 2014 due to factors related to costs, revenues, and competitiveness of the program. Alumni reaction was so strong against the decision, in May $2015 \mathrm{UAB}$ reinstated the program after $\$ 17.2$ million private money was raised to cover the program’s costs.

Tier 3 schools would be small-to-medium-sized state-supported schools; a good example would be University of Wisconsin - Green Bay (UWGB), where a much smaller and more targeted and refined complement of collegiate sports teams are deployed. UWGB's strategy is to focus support on NCAA division 1 teams (primarily men's and women's basketball) that are cost effective and can potentially yield broad exposure (i.e., for example, if the UWGB men's or women's basketball team earns a slot in the NCAA division 1 national tournament, they will be part of an event watched by tens of millions of viewers). The brand equity associated with the school can be enhanced significantly (particularly in the short term) by the success of these targeted sports programs. As the athletic director at Northwestern Midwest College (NMC), Jack perceived his school as being closest to the Tier 3 category.

\section{CONCLUSION AND IMPORTANT QUESTIONS}

After doing some initial research, Jack realized that the success of collegiate sports programs has become more and more relevant to the recruiting, retention and development fund activities of many colleges and universities. He also realized that smaller and medium-sized schools will increasingly question the efficacy of their sports program investments and will begin to think more strategically about these same investments.

Jack then had an idea and thought it would be interesting to have either an undergraduate or graduate (MBA) marketing strategy class take this up as a class project. He developed a series of questions (listed below) which would serve as the basis for the course project and placed a telephone call to one of the marketing professors he knew on campus to see if this project could be done in one of the classes. Jack also had a close friend who was an athletic director at a similar-sized university in another state (Wendy Applebaum), and also placed a call to this friend to see if she would be willing to do the same thing (i.e., have students in a marketing strategy class conduct some analysis focused on the below-listed questions), and then both Jack and Wendy would share their results with one another. Jack was eager to see if all of this could be accomplished, and what the results might tell him about the future of the sports programs on the NMC campus. 


\section{DISCUSSION QUESTIONS}

1. Looking at the array of sports programs on your campus, develop an analysis of each of the specific sports programs looking a key metrics such as \$ revenue generated, \$ cost, annual fan attendance, \# of student athletes involved, and trends (growth, stability, decline) over the past 5 years.

2. Again looking at your own university, are there sports programs which you think should be added, and if so, why? Prepare a brief business plan for your proposed (additional) sports program, and present this plan to your class.

3. Similarly, again looking at your own university, are there sports program which you think should be deleted, and if so, why? Again, prepare a brief presentation to make the case for program deletion. How might current students react? How might alumni react?

4. The area of e-sports is growing in significance and several colleges are jumping on the bandwagon to add facilities as well as scholarship support for teams. There is even some discussion to have e-sports featured as a "demonstration sport" in the upcoming 2024 Summer Olympics. Should your university consider establishing an e-sports team, and/or begin to develop an e-sports league within your region? Should the NCAA move towards establishing a sanctioned esports? What about other examples of sports which are a bit outside of the mainstream, such as rodeo, timber sports / lumberjack competitions, or snowboarding / freestyle skiing; should your university consider investing in a team related to one of these?

5. What would you consider to be the ideal "mix" of sports on your campus? Prepare a brief analysis related to this question and present your results to the class. How easy or difficult might it be to implement your proposed ideal "mix"? Why or why not?

\section{TEACHING NOTES}

Teaching notes are available from the first-listed author (email: gbrunswi@nmu.edu)

\section{ACKNOWLEDGEMENTS}

Portions of this case include content that was developed in two earlier presented and published conference papers (American Society of Business and Behavior Sciences $4^{\text {th }}$ Annual Conference, and the Allied Academies International Conference).

\section{AUTHOR BIOGRAPHIES}

Gary J. Brunswick holds a Ph.D. in Business Administration from Arizona State University, and currently holds the rank of Professor of Marketing at Northern Michigan University. His research interests include marketing strategy, services marketing and e-commerce. His research has been published in a range of journals, including the Journal of the Academy of Marketing Science, Journal of Consumer Behaviour, The Marketing Management Journal, The Journal of Professional Services Marketing, The Journal of Business and Economics Research, The International Journal of Case Studies and Research, The Journal of the International Academy of Case Studies, The Academy of Educational Leadership Journal, the Journal of Business Case Studies, and The Academy of Marketing Studies Journal. E-mail: gbrunswi@nmu.edu

Brian A. Zinser earned a DBA in Marketing from the Falls School of Business at the Anderson University, Indiana. He is currently a member of the Marketing Faculty at the Northern Michigan University. He served on the Faculty of Lake Superior State University from 2005-2014. Previously, he spent nearly 20 years in marketing management positions in the financial services industry as well as served for more than five years as a Director of Marketing for the Northern Michigan University. 


\section{REFERENCES}

Aaker, D. (1991). Managing brand equity: Capitalizing on the value of a brand name. New York: The Free Press.

Aaker, D. (1996). Building strong brands. New York: The Free Press.

Brady, E. Berkowitz, S. \& Schnaars, C. (2015, May 26). College athletics finance report: Non-power 5 schools face huge money pressure. USA Today. Retrieved from https://www.usatoday.com/story/sports/college/2015/05/26/ncaa-athletic-financesrevenue-expense-division-i/27971457/

Brunswick, G. (2005, July). Proceedings of Allied Academies International Conference, Academy of Marketing Studies: Higher education and the marketing of intercollegiate sports programs: A portfolio approach. 10(1), 1-3.

Brunswick, G. (1997, February). Proceedings of the American Society of Business and Behavior Sciences Annual Conference, Las Vegas, Nevada: Extending the concept of brand equity to colleges and universities.

Fulks, D. (2015). Revenue \& expenses 2004-2014: NCAA division I intercollegiate athletics programs report. Retrieved from NCAA website: https://www.ncaa.org/sites/default/files/2015\%20Division\%20I\%20RE\%20report.pdf

Gladden, J., Milne, G., \& Sutton, W. (1998). A conceptual framework for assessing brand equity in Division I college athletics. Journal of Sport Management, 12(1), 1-19. doi: 10.1123/jsm.12.1.1

Leeds, M., von Allmen, P., A. Matheson, V. (2018). The economics of sports. New York: Routledge.

Sander, L. (2008, September 19). Athletics raises a college from the ground up. The Chronical of Higher Education. Retrieved from https://www.chronicle.com/article/Athletics-Raises-a-College/35098

Sperber, M. (2001), Beer and circus: How big-time college sports is crippling undergraduate education. New York: Owl Books. Zimbalist, A. (1999), Unpaid professionals: Commercialism and conflict in big-time college sports. Princeton, NJ: Princeton University Press. 


\section{NOTES}

